\title{
Resources on the Net:
}

\section{Digital Resources and Education Libraries}

By Anne Wade, Concordia University, Canada

\section{Selected e-journals}

Canada's Schoolnet Magazine. Published by Industry Canada/SchoolNet, this magazine provides profiles innovative uses of technology in Canadian schools. Available: http://www.schoolnet.ca/magazine/e/

From Now On: an educational technology journal with articles of interest to educators and librarians. Available: http://www.fromnowon.org.

Learning and Leading with Technology. Published by the International Society for Technology in Education Available: http://www.iste.org/L\&L/archive/vol28/no8/ index.html

Learning Technology. A publication of IEEE Computer Society Learning Technology Task Force (LTTF) Available: http://lttf.ieee.org/learn_tech/

Learning Technology Review. Published by Apple Computer. Includes articles on teachers' experiences using technology in the classroom. Available: http:// www.apple.com/education/LTReview/fall99/

Multimedia Schools. A practical how-to magazine sharply focused on the needs of school practitioners. Articles, reviews, and columns address issues associated with using electronic information resources in $\mathrm{K}-12$ schools-Internet, online and multimedia databases, CD-ROM technology, computer hardware and software. Available: http://www.infotoday.com/ MMSchools/

OnlineClass. This monthly e-mail newsletter contains tips on how to use the Internet in the classroom, technology reports, updates on our programs, and comments from educators using the Internet in the classroom. Available: http://www.onlineclass.com/ General/contactus.html

Syllabus Magazine. Includes feature articles, case studies, product reviews, and profiles of technology use at the instructor, departmental, and institutional levels. Available: http://www.syllabus.com.

\section{Classroom Resources}

Apple Computer. (2001). Apple learning interchange. Available: http://ali.apple.com/ali/ (2001, September 1).

Apple has a long history of a strong presence in the educational technology field for K-12. This site includes links to two incredible databases of resources: Units of Practice and Learning Resources, filled with curricular ideas for teachers. Also includes articles on professional development and technology use in schools.

Canada's Schoolnet. (2001). Available:

http://www.schoolnet.ca/home/e/ (2001, September 1).

An excellent source of educational web sites with over 5,000 Learning Resources, @SchoolNet Today, a daily information news services on the world of e-learning, and interactive features.

Franklin Institute. (2001). The Franklin Institute online: Collections and investigations. Available:

http://www.fi.edu/learning.html (2001, September 1).

Contains learning resources divided into sites for collections of material and investigations (actual classroom-based activities).

George Lucas Educational Foundation. (2001). Available: http://glef.org (2001, August 25).

This web site is rich in articles (downloadable in .pdf files) subject information and curriculum information, and a guide, Teaching in the Digital Age. Feature stories focus on schools that use innovative methodologies.

Harris, J. (2000, April). Virtual architecture.

Available:

http://ccwf.cc.utexas.edu/\%7Ejbharris/

Virtual-Architecture/Foundation/index.html.

An e-book which explores and categorizes effective teleteaching and learning in depth. Chapters were originally published in Learning and Leading with Technology. 
IBM Canada. (no date). Teacher's Toolkit. Available: http://www.can.ibm.com/k12/Resource_websites.htm (2001, August 26).

Geared to K-12 teachers and students this site provides a comprehensive list of General Interest Web sites (useful for classroom projects), Schools on the Web, Teacher Resources and Lesson Plans, Cool Sites for Kids, Continuing Education for K-12 Educators, and K12 Educational Resources and Directories. It didn't list the NASA sites under Cool Sites for Kids and currency of the links is unknown as there is no date on the site, however, the site is a good resource.

Kidsclick. (2001). Kidsclick! Web search for kids by librarians. Available: http://sunsite.berkeley.edu/ KidsClick!/ (2001, September 1).

Provides a safe and relevant environment for students to search for web-based information. Users can perform a keyword search or search by subject directory (by subject area or Dewey Decimal classification). Also provides a step by step, simple guide to teaching children how to search on the Internet.

National Council of Teachers of Mathematics. (2001, August 31). NCTM Illuminations. Available: htttp:// illuminations.nctm.org/lessonplans/index.html (2001, September 1).

Geared for PreK-12 teachers, this site provides InternetBased Lesson Plans as examples of how Internet links can be used to help create effective Standards-based mathematics lessons.

National Council on Economic Education. (2001, Augusat 31). CyberTteach. Available: http:// www.econedlink.org/cyberteach/ (2001, September 1).

CyberTeach is a comprehensive guide to teaching economics using the Internet. Applicable to all grade levels and subject areas, this site contains EconEdLetter, information on basic web skills, model lessons, and templates for creating effective lesson plans.

National Endowment for the Humanities. (2001). EDSITEMent. Available: http://edsitement.neh.gov/ (2001, September 1).

Provides subject-based access to top humanities sites, EDSITEment lesson plans and at-home activities, and additional learning activities.

New York Times. NYT Learning Network. Available: http://nytimes.com/learning (2001, September 1).
This site provides an interactive learning experience for teachers and students, based on the daily edition of the New York Times. Look at the Day in the News, the Lesson Plans (including an Archive of Plans), and enjoy the integration of the New York Times with curriculum planning.

\section{Quebec English Schools Network. (2001). Portfolio} process.

Available: http://www.qesn.meq.gouv.qc.ca/portfolio/ port_eng.html (2001, September 1).

This bilingual site is designed to provide as many tools and resources as possible to teachers and their students working with the portfolio process, including digital portfolios. Some of the tools on this site have been developed to be used with professional development workshops. Includes links to theoretical information as well.

Schrock, K. ( 2001). Kathy's Schrock's guide for educators. Available: http://school.discovery.com/ schrockguide/assess.html (2001, August 25).

As the title suggests, Kathy's extensive web site is geared primarily to educators, providing them with endless links to resources. This specific page provides a series of links to assessment rubrics for use on the World Wide Web. One of the links on web page evaluation is to a set of evaluation criteria (http:/l www.ux1.eiu.edu/ cfmgb/web.htm), Sites are scored according to Ideas and Content, Organization, Technical, Language, and Presentation. Very good resource for teachers.

ThinkQuest. Teaching Tomorrow's Teachers. (no date). Available: http://t3.thinkquest.org/ (2001, September 1).

The ThinkQuest site is divided into "Labs" representing different aspects of the ThinkQuest for Tomorrow's Teachers (T3) program. These seven labs are: Partners, Project, Teaching and Learning, Resource, Communication, Writing and Evaluation. The laboratory metaphor is used because T3 is a place of active research and exploration. Exploring new teacher/learner relationships and new paradigms for using digital and networking technologies as tools in enhancing learning is the T3 vision for education.

Yee-Rong Lai \& Levin, S. \& Levin, J. (Eds.) (1998, June 17). Teaching Teleapprenticeship Project. Available: http:///rs.ed.uiuc.edu/TTA (2001, August 25).

Funded by the NSF, the Teaching Teleapprenticeship Project (TTA) at the University of Illinois at UrbanaChampaign is developing and evaluating innovative 
teacher education models. These models extend the traditional face-to-face apprenticeships currently used in student teaching by using electronic networks to provide a more powerful context for learning in pre-service and in-service education courses.

\section{Issues Related to Digital Resources}

\author{
Becker, H. (1999, February 12). Internet use by \\ teachers. Available: http://www.crito.uci.edu/TLC/ \\ FINDINGS/internet-use/ (2001, August 25).
}

This in-depth report provides a revised and more extended analysis of an earlier paper (1998) of the same data. It includes information about how frequently teachers and students use the Internet and in what ways, to what extent teachers value having the Internet in their own classroom, how much access teachers have to the Internet, and Internet use and value by the teacher's pedagogical approach. Unfortunately this reviewer has been unable to locate anything more recent.

\section{Collaborative for Technology Standards for School Administrators. (2001, Aug 28). Technology standards for school administrators TSSA Draft (v3.0). Available: http://cnets.iste.org/tssa/ view_standards.html (2001, September 1, 2001).}

The Collaborative for Technology Standards for School Administrators (TSSA Collaborative) is leading an initiative to develop a national consensus on what PK12 administrators should know and be able to do to optimize technology use in schools. They have posted of drafts of their standards for review and feedback. The final consensus is published by the Collaborative (October, 2001) as Technology Standards for School Administrators (TSSA).

Copyright Clearance Center. (2001). Available: http://www.copyright.com (2001, August 26).

The Copyright Clearance Center (CCC) is the largest licenser of text reproduction rights in the world, providing licensing systems for the reproduction and distribution of copyrighted materials in print and electronic formats throughout the world. The company currently manages rights relating to over 1.75 million works and represents more than 9,600 publishers and hundreds of thousands of authors and other creators. CCC-licensed customers in the U.S. number over 10,000 corporations and subsidiaries as well as thousands of government agencies, law firms, document suppliers, libraries, academic institutions, copy shops and bookstores. This well designed and easy to use site provides links to permissions for print or digital material, for academic and corporate users.

Davidson, H. (1999, September). The educator's no fat lean guide to copyright and fair use. Technology

\& Learning Magazine. Available: http://

www.techlearning.com/content/speak/articles/ copyright.html (2001, August).

Executive Director of Educational Services and Telecommunications at KOCE-TV in California, Hall outlines his common sense rules entitled "The No FAT (Fear And Trembling) Educators' Gray Area Guide to Fair Use." He also provides a useful summary of how educators can use multimedia, providing a breakdown by type of media.

Gasaway, L. (1999, September 10). When works pass into the public domain. Available: http:// www.unc.edu/ unclng/public-d.htm (2001, August 25). Excellent chart that summarizes the date of work, when it was protected from, and the term of protection.

Ryan, J. (1998, December). Student plagiarism in an online world. Prism Online. Available: http:// www.asee.org/prism/december/html/ student_plagiarism_in_an_onlin.htm (2001, August 20).

Ryan calls attention to the ease in which students can now plagiarize because of the accessibility of information. She also provides some tricks for professors and states that "The laziness that prompts students to cheat can also prompt them to do a terrible job with their plagiarism."

Patricia O'Brien Libutti contributed links and annotations to this column.

This is the fourth in a column entitled Resources on the Net. This column will contain a variety of interesting and informative sites on special topics of interest to education librarians. It is hoped that readers will find many of these sites worth bookmarking for future reference. Please feel free to contact the author at: wada@education.concordia.ca

Anne Wade (M.L.I.S., '86) is a Research Coordinator and Information Specialist at the Centre for the Study of Learning and Performance, Education Department, Concordia University and a Lecturer in the Information Studies Program, Concordia University, Canada. 